\title{
Cytosolic Free Calcium and Cell Death during Metabolic Inhibition in a Neuronal Cell Line
}

\author{
Michael E. Johnson, ${ }^{1}$ Gregory J. Gores, ${ }^{2}$ Cindy B. Uhl, ${ }^{1}$ and J. Christopher Sill ${ }^{1}$ \\ 'Department of Anesthesiology and ${ }^{2}$ Center for Basic Research in Digestive Diseases, Mayo Foundation, Rochester, \\ Minnesota 55905
}

Elevated free cytosolic $\mathrm{Ca}^{2+}\left(\mathrm{Ca}^{2+}{ }_{j}\right)$ has been implicated as a mechanism of hypoxic neuronal death. The calcium hypothesis postulates that the basic metabolic response to hypoxic ATP depletion is a toxic increase in free cytosolic $\mathrm{Ca}^{2+}$, in all cell types. This inherent response then creates the environment in which subsequent derangements of $\mathrm{Ca}^{2+}$, may occur, for example, from glutamate excitotoxicity. Although the effect of glutamate on neuronal $\mathrm{Ca}^{2+}{ }_{\text {i }}$ has been extensively studied, the basic neuronal response to hypoxia independent of glutamate receptor activation is not well defined. We therefore assayed both $\mathrm{Ca}^{2+}$, and plasma membrane integrity in fura-2-loaded, single SK-N-SH neuroblastoma cells, using digitized video microscopy and metabolic inhibition ( $2.5 \mathrm{~mm} \mathrm{NaCN}, 10 \mathrm{~mm}$ 2-deoxyglucose) to model the ATP depletion of hypoxia.

Median time to cell death was $90 \mathrm{~min}$ ( $n=51$ cells). Initial $\mathrm{Ca}^{2+}{ }_{i}$ was $121 \pm 67 \mathrm{~nm}$. $\mathrm{Ca}^{2+}{ }_{j}$ increased by $50 \mathrm{~nm}$ after 5-10 min of metabolic inhibition. Blebbing of the cell membrane was evident within $30 \mathrm{~min}$. $\mathrm{Ca}^{2+}{ }_{i}$ did not appreciably increase further until the time of cell death, when the loss of plasma membrane integrity allowed unimpeded influx of extracellular $\mathrm{Ca}^{2+}$. Although the increase in $\mathrm{Ca}^{2+}$, prior to cell death was statistically significant, it is unlikely to be physiologically significant, because (1) percentage change in $\mathrm{Ca}^{2+}$, accounted for only $13 \%$ of the variation in time to cell death, in a linear regression model; (2) some cells died in less than the median $\mathbf{9 0}$ min despite having decreases or very slight increases in $\mathrm{Ca}^{2+}$, during metabolic inhibition; and (3) the omission of $\mathrm{Ca}^{2+}$ from the experimental buffer prevented an increase in $\mathrm{Ca}^{2+}$, but did not prevent cell death during metabolic inhibition. In contrast, cells exposed to oxidative stress ( $1 \mathrm{mM} \mathrm{H}_{2} \mathrm{O}_{2}$ ) as a positive control showed a severalfold increase in $\mathrm{Ca}^{2+}$, prior to cell death, greater than the change seen in any metabolically inhibited cell. In conclusion, in the absence of glutamate receptors, $\mathrm{Ca}^{2+}{ }_{i}$ increases minimally during metabolic inhibition in SK-N-SH cells, and this increase does not appear to contribute to the mechanisms of cell death.

[Key words: calcium, neuroblastoma, hypoxia, neuronal ischemia, metabolic inhibition, cyanide, 2-deoxyglucose, fura-2]

\footnotetext{
Received July 19, 1993; revised Dec. 13, 1993; accepted Jan. 20, 1994

This work was supported by a Mayo Foundation CR20 grant to M.E.J., NIH Grant DK 41876 to G.J.G., and NIH Grant HL 38668 to J.C.S. We thank Dr. W. L. Lanier for critiquing the manuscript.

Correspondence should be addressed to Michael E. Johnson, M.D., Ph.D. Department of Anesthesiology, Mayo Clinic, Rochester, MN 55905.

Copyright (C) 1994 Society for Neuroscience $0270-6474 / 94 / 144040-10 \$ 05.00 / 0$
}

The calcium hypothesis postulates a central role for elevated cytosolic free calcium $\left(\mathrm{Ca}^{2+}{ }_{i}\right)$ in hypoxic cell death. In neurons, the calcium hypothesis is supported by studies showing an accumulation of $\mathrm{Ca}^{2+}{ }_{i}$ in ischemic brain and tissue slices, and protection during ischemia by calcium channel antagonists and lowered extracellular $\mathrm{Ca}^{2+}$ (Choi, 1988; Uematsu et al., 1988; Meyer, 1989; Siesjö, 1989; Siesjö and Bengtsson, 1989; Siesjö et al., 1991). The calcium hypothesis has been particularly productive in providing a framework to study glutamate excitotoxicity, which is thought to occur during neuronal hypoxia (Ogura et al., 1988; Goldberg and Choi, 1990; Siesjö et al., 1991; Hartley et al., 1993), although changes in $\mathrm{Ca}^{2+}{ }_{\text {, }}$ have not always correlated with toxicity (Dubinsky and Rothman, 1991; Dubinsky, 1993). However, the calcium hypothesis also postulates a harmful increase in $\mathrm{Ca}^{2+}$, as the basic cellular response to hypoxia in all cell types, independent of excitotoxicity. Potential mechanisms include increased $\mathrm{Ca}^{2+}{ }_{i}$ permeability and decreased ion pump activities during hypoxia, and subsequent activation of intracellular proteases, phospholipases, and cndonuclcases (Siesjö, 1986, 1989; Siesjö and Bengtsson, 1989; Trump et al., 1989; Farber, 1990; Kluge, 1991; Orrenius et al., 1991). The calcium hypothesis is still actively investigated in studies of myocardial, hepatic, and renal hypoxia (Marsh and Smith, 1991; Gasbarrini et al., 1992; Wetzels et al., 1992; van Zwieten, 1993). In contrast, the question of whether $\mathrm{Ca}^{2+}{ }_{i}$ increases during neuronal hypoxia independent of excitotoxicity and other extracellular influences has not been definitively answered, even though the basic cellular response to hypoxia creates the environment in which any other effect, such as excitotoxicity, must operate. For example, a glutamate-induced increase in $\mathrm{Ca}^{2+}{ }_{i}$ would more likely be toxic if hypoxia had already caused a derangement of $\mathrm{Ca}^{2+}{ }_{i}$ homeostasis and elevation of $\mathrm{Ca}^{2+}{ }_{i}$. Furthermore, the mechanism of nonglutamatergic neuronal death is also of interest for peripheral neurons that may be involved in an acute ischemic insult (Kroll et al., 1990).

The cell biology of calcium itself imposes significant experimental constraints in addressing the basic neuronal response to hypoxia. Many previous studies using various calcium assays and ischemic neural tissue are limited by the enormous concentration gradient (roughly $10^{4}$ ) between cytosolic and extracellular free $\mathrm{Ca}^{2+}$. Therefore, when a tissue is made hypoxic and some cells begin to die, their apparent $\mathrm{Ca}^{2+}{ }_{i}$ will rise enormously; however, this is simply a postnecrotic phenomenon accompanying loss of plasma membrane integrity, not the mechanistic cause of cell death (Cheung et al., 1986). Furthermore, the use of radioactive calcium or microanalysis to determine intracellular calcium, even in a live cell, does not distinguish between elevated calcium in the endoplasmic reticulum and mitochon- 
dria, which function normally as calcium reservoirs and buffers, and elevated calcium in the cytosol, $\mathrm{Ca}^{2+}{ }_{i}$, which is the postulated etiologic agent of calcium-mediated hypoxic damage (Cheung et al., 1986; Choi, 1988; Siesjö, 1989; Siesjö and Bengtsson, 1989). Experiments with calcium channel antagonists are limited by their effects on the heart and vasculature in the whole animal or perfused organ, and by their effects at other receptors and ion channels in isolated cell experiments (Miller, 1987; Partridge and Swandulla, 1988; Kostyuk, 1991; Wetzels et al., 1992; van Zwieten, 1993).

To determine the true relationship of $\mathrm{Ca}^{2+}{ }_{i}$ to hypoxic cell death, it is helpful to perform experiments at the level of the single cell, using a calcium indicator such as fura-2 that is localized to the cytoplasm under appropriate loading conditions. When such experiments have been performed on hepatocytes, they have shown that the change in $\mathrm{Ca}^{2+}{ }_{i}$ prior to cell death from metabolic inhibition (cyanide and iodoacetate) is either negligible (Lemasters et al., 1987) or moderate (150 nм) and bears no relationship to cell death (Nieminen et al., 1988). The assumption that elevated $\mathrm{Ca}^{2+}{ }_{i}$ is inevitably neurotoxic has also been called into question by the finding that embryonic ciliary ganglion neurons require elevated $\mathrm{Ca}^{2+}{ }_{i}$ (> $1000 \mathrm{~nm}$ ) for survival during maturation, and that the survival of other neurons in culture is promoted by depolarization with high potassium, which also raises $\mathrm{Ca}^{2+}{ }_{i}$ (Collins et al., 1991).

To clucidate further the role of $\mathrm{Ca}^{3+}{ }_{i}$ in the basic neuronal response to hypoxia, independent of excitotoxicity and other extracellular factors, we utilized the cell line SK-N-SH, which is derived from human neuroblastoma and has been well characterized as a neuronal model (Sadée et al., 1987; Fisher et al., 1989; Lambert et al., 1989). To simulate hypoxia conveniently on the microscope stage, we used cyanide and 2-deoxyglucose to produce metabolic inhibition. To distinguish between preand postnecrotic changes in $\mathrm{Ca}^{2+}{ }_{i}$, and to prevent the averaging and loss of information that accompany assay of large cell numbers, we measured $\mathrm{Ca}^{2+}{ }_{i}$ and determined the time of cell death in single cells using fura-2 digitized video microscopy. We tested the hypotheses that (1) metabolic inhibition causes an increase in $\mathrm{Ca}^{2+}{ }_{i}$ prior to neuronal death, and (2) increases in $\mathrm{Ca}^{2+}{ }_{i}$ are correlated with the rapidity of neuronal cell death during metabolic inhibition.

\section{Materials and Methods}

Chemicals. Fura-2 AM ester, fura-2, and 4-bromo-A23187 were obtained from Molecular Probes, Eugene, Oregon. Fetal calf serum was obtained from Hyclone (Logan, UT). All other chemicals were purchased from Sigma (St. I ouis, MO).

Cell culture. SK-N-SH was obtained from the American Type Culture Collection, Rockville, MD, at passage 34. Cells were grown in RPMI supplemented with $10 \%$ fetal calf serum at $37^{\circ} \mathrm{C}$ in air $/ 6 \% \mathrm{CO}_{2}$, and fed every 2-3 d. Cells for experiments were trypsinized briefly, replated on glass coverslips in medium lacking phenol red, and incubated on the coverslips inside $35 \times 10 \mathrm{~mm}$ culture plates (Primaria Falcon) overnight prior to experiments. All cells used for experiments were from passages $35-47$.

No neuroblastoma cell line is known to form neural synapses (Banker and Goslin, 1991a), and no synapses were found during electron microscopic examination of SK-N-SH (Barnes et al., 1981). During culture of SK-N-SH, a small number of epithelial-like cells typically appear that lack neurotransmitter receptors and synthesis. These are readily distinguishable from the neuronal cells by morphology alone-all cells with a neuronal phenotype have processes resembling neurites and are much smaller than the epithelial-like cells (Ross et al., 1983). Cellular morphology correlates absolutely with neural phenotype-cells with neuroblast morphology express tyrosine hydroxylase, dopamine $\beta$-hydroxylase, $\mu$ and $\delta$ opioid receptors, muscarinic cholinergic receptor coupled to phosphoinositol turnover, and catecholamine uptake transporter, while cells with epithelial morphology express none of these neural characteristics (Sadée et al., 1987). All cells used for our experiments had typical neuroblast morphology with neurite-like processes These processes were present at all stages of culture, except in the epithelial-like cells. Expression of the neuroblast phenotype is constitutive no inducers were added to cause differentiation. Predominance of neuroblasts over epithelial cells is encouraged by culture at low initial cell density (Sadée et al., 1987), which was our practice, so that all cells used for experiments were actively growing and probably in log growth phase. Although we did not obtain quantitative growth curves, doubling time of cells prepared on coverslips as if for an experiment, and then allowed to grow instead of being exposed to metabolic inhibition, was grossly similar to the doubling time of cells in regular culture, about 24 hr.

Measurement of cytosolic free calcium using fura-2 and multiparameter digitized video microscopy. Cells were loaded with fura- 2 by incubating a coverslip with $1 \mathrm{ml}$ of culture medium containing $5 \mu \mathrm{M}$ fura-2 $\mathrm{AM}$, for $30 \mathrm{~min}$ in air $/ 6 \% \mathrm{CO}_{2}$ at $37^{\circ} \mathrm{C}$. The cells were then washed with KRH buffer ( $25 \mathrm{~mm}$ HEPES, $115 \mathrm{~mm} \mathrm{NaCl}, 5 \mathrm{~mm} \mathrm{KCl}, 1.2 \mathrm{~mm}$ $\mathrm{MgSO}_{4}, 1.0 \mathrm{~mm} \mathrm{KH} \mathrm{PO}_{4}, 2.0 \mathrm{~mm} \mathrm{CaCl}$, $+\mathrm{NaOH}$ to $\left.\mathrm{pH} 7.4\right)$. The coverslip was mounted on a microscope stage chamber, and covered with $1.0 \mathrm{ml}$ of $\mathrm{KRH}$. The coverslip was kept at $37.0^{\circ} \mathrm{C}$ with a Zeiss TRZ3700 thermostatically controlled microscope stage heater.

Ratio imaging of fura-2 fluorescence was performed using multiparamcter digitizcd vidco microscopy. Two imaging systems were used, both of which gave similar results in control experiments: an Image-1/ FL software-based system as previously described (Universal Imaging Corp., West Chester, PA) (Groskreutz et al., 1992), using excitation filters of 340 and $360 \mathrm{~nm}$, or an Attofluor RatioVision system (Atto Instruments, Rockville, MD) equipped with an ICCD camera and a Zeiss Axiovert 135TV inverted microscope, using excitation filters of 334 and $360 \mathrm{~nm}$. For each system, eight video frames were averaged to obtain each fluorescence image. Cells were completely shielded from the excitation light except when images were being acquired. Total exposure to excitation light was $<0.3 \mathrm{sec}$ for each pair of 340 and 360 $\mathrm{nm}$ images, acquired at 2.5-4 min intervals. Backgrounds were acquired using a portion of the coverslip free of cells, and background fluorescence was subtracted from each image on a pixel-by-pixel basis prior to ratio calculations or further analysis. The ratio $(R)$ of $340 \mathrm{~nm}$ excitcd fluorescence to that at $360 \mathrm{~nm}$ fluorescence $\left(F_{360}\right)$ was converted to $\mathrm{Ca}^{2+}$ concentration using the calibration equation previously described (Grynkiewicz et al., 1985),

$$
\left[\mathrm{Ca}^{2+}{ }_{i}=K_{d}\left(R-R_{\min }\right)\left(R_{\max }-R\right)^{-1}\left(F_{360}\left[-\mathrm{Ca}^{2+}\right] / F_{360}\left[+\mathrm{Ca}^{2+}\right]\right),\right.
$$

with $K_{d}=224$ nM. $R_{\min }$ and $R_{\max }$ and $\mathrm{F}_{360}\left(\mathrm{Ca}^{2+}\right)$ were determined for each experiment with standard solutions of fura-2 free acid in $115 \mathrm{~mm}$ $\mathrm{KCl}, 20 \mathrm{mM} \mathrm{NaCl}, 10 \mathrm{~mm} \mathrm{~K}-\mathrm{MOPS}, \mathrm{pH} 7.2$, containing either $2 \mathrm{~mm}$ $\mathrm{CaCl}_{2}$ or $10 \mathrm{~mm}$ EGTA for $\pm \mathrm{Ca}^{2+}$, visualized in glass capillary rods of $20 \mu$ internal diameter (Vitro Dynamics, Rockaway, NJ). For analyzing a single cell, ratios were calculated on a pixel-by-pixel basis, and then $\left[\mathrm{Ca}^{2+}{ }_{i}\right]$ was calculated for each pixel. The $\mathrm{Ca}^{2+}{ }_{i}$ concentrations for each pixel in a cell's image were then averaged to give the cellular $\mathrm{Ca}^{2+}{ }_{i}$ value reported.

Other microscope analyses. Concurrent imaging of propidium iodide and fura-2 fluorescence during an experiment was performed by adding $500 \mathrm{~nm}$ propidium iodide to the experimental buffer, and by switching optical filters between exposures. Propidium iodide fluorescence was acquired with $490 \mathrm{~nm}$ excitation, $580 \mathrm{~nm}$ dichroic, and 630 long-pass emission filters. Fura-2 fluorescence was acquired with 340 and $360 \mathrm{~nm}$ excitation, $510 \mathrm{~nm}$ dichroic, and 515-565 nm emission filters. Phasecontrast images were acquired with a Zeiss $63 \times, 1.25$ NA, oil, Ph3 Plan, Neofluar lens; fluorescence images were also acquired through this lens when phase images were being analyzed. Otherwise, fluorescence images were acquired through a $Z$ eiss $40 \times, 1.30 \mathrm{NA}$, oil, Plan, Neofluar lens.

Metabolic inhibition. Cells were allowed to incubate $10-20 \mathrm{~min}$ to attain a stable baseline of $\mathrm{Ca}^{2+}$, values, and then metabolic inhibition was initiated (at $0 \mathrm{~min}$ on all graphs) by adding the respiratory inhibitor $\mathrm{NaCN}(2.5 \mathrm{~mm}$ final concentration) and the glycolytic inhibitor 2-deoxyglucose (10 mM final concentration) (Hochster, 1963; Lemasters et al., 1987; Nieminen et al., 1988; Lemasters et al., 1990). The addition of 2-deoxyglucose inhibits glycolytic production of ATP (Hochster, 1963) because its metabolite, 2-deoxyglucose-6-phosphate (2dG6P), competitively inhibits phosphoglucose isomerase. Metabolism of 2-deoxyglucose 


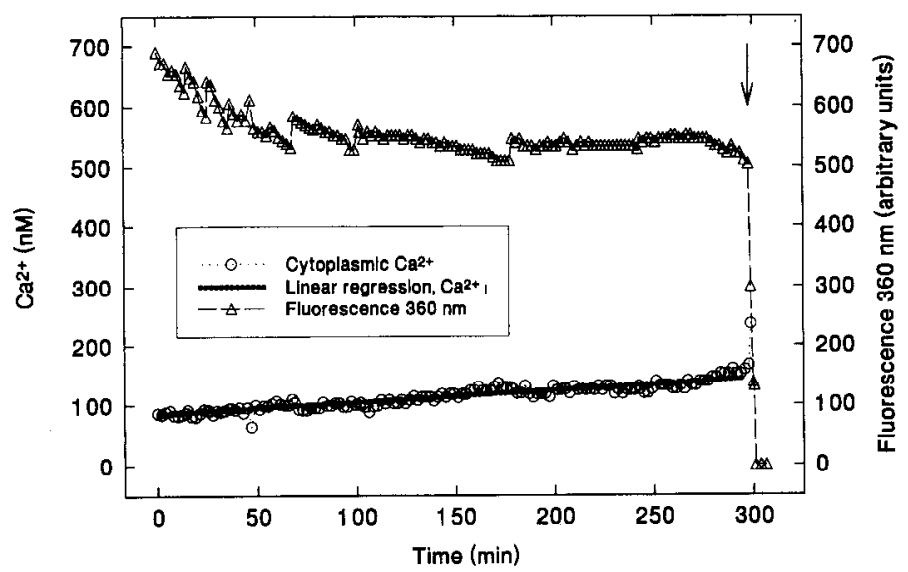

Figure 1. Effect of control incubation on single SK-N-SH cell. The cell was placed in KRH buffer with no metabolic inhibitors added, and fluorescent images acquired at the times indicated. The arrow indicates the addition of $20 \mu \mathrm{M}$ digitonin to lyse selectively the cytoplasmic membrane and leave organelles intact. Linear regression of $\mathrm{Ca}^{2+}$, values prior to digitonin addition yielded $\mathrm{Ca}^{2+}{ }_{i}=0.204 \times($ time, in min $)+83.07$, with $r^{2}=0.87$. One cell typical of 20 .

to $2 \mathrm{dG} 6 \mathrm{P}$ also depletes ATP, since a high-energy phosphate from ATP is transferred to a metabolite $(2 \mathrm{dG} 6 \mathrm{P})$ that cannot be further metabolized. A concentration of $10 \mathrm{~mm}$ was chosen to give maximal inhibition without undue osmotic perturbations, based on published reports (Hochster, 1963), and was found experimentally to speed the rate of cyanide-treated SK-N-SH cell death enough to allow the experiments described here.

ATP analysis. Cultures in $35 \times 10 \mathrm{~mm}$ plates were exposed to metabolic inhibition or to $5 \mathrm{~mm}$ glucose, both in air, in KRH buffer, at $37^{\circ} \mathrm{C}$. The cultures were then extracted wilh acetonitrile as described previously (Au et al., 1989). Each extract was lyophilized and reconstituted with $0.10 \mathrm{ml}$ of $100 \mathrm{~mm}$ potassium phosphate $\mathrm{pH} 5.9$, and then analyzed by HPLC as described previously (Jones, 1981).

Analysis of changes during metabolic inhibition. Images were acquired at $2.5-4.0 \mathrm{~min}$ intervals. Because $360 \mathrm{~nm}$ is near the isosbestic point of the fura-2 excitation spectra when $\mathrm{Ca}^{2+}$ is varied, the amount of fura- 2 left in the cell is proportional to the average fluorescence above background within the houndary of the cell seen with $360 \mathrm{~nm}$ excitation, multiplied by the number of non-zero pixels left within the boundaries of the cell (Nieminen et al., 1988; Bronk and Gores, 1991). This product, the two-dimensional representation of fura- 2 concentration, is referred to as "fluorescence $360 \mathrm{~nm}$ " in this article. For graphical display, fluorescence $360 \mathrm{~nm}$ was multiplied by a constant to put it on the same axis as $\mathrm{Ca}^{2}$, since it is the change rather than the absolute value of fluorescence $360 \mathrm{~nm}$ that is important in determining cell death. The time of cell death was calculated as the first point in the sustained decrease of fluorescence $360 \mathrm{~nm}$ to zero. Initial $\mathrm{Ca}^{2+}{ }_{i}, \mathrm{Ca}^{2+}{ }_{i}\left(t_{0}\right)$, was calculated by averaging the last two $\mathrm{Ca}^{2+}{ }_{i}$ values prior to the initiation of metabolic inhibition. $\mathrm{Ca}^{2+}$, halfway to cell death, $\mathrm{Ca}^{2+},\left(t_{1 / 2}\right)$, was calculated by averaging the two values closest to (time of cell death) $/ 2$. Percentage change in $\mathrm{Ca}^{2+}$, at $t_{1 / 2}$ was calculated as

$$
\% \Delta \mathrm{Ca}^{2+}{ }_{,}\left(t_{1 / 2}-t_{0}\right)=100 \% \times\left[\mathrm{Ca}^{2+}{ }_{i}\left(t_{1 / 2}\right)-\mathrm{Ca}^{2+}{ }_{(}\left(t_{0}\right)\right] / \mathrm{Ca}^{2+}{ }_{i}\left(t_{0}\right) \text {. }
$$

Data were analyzed statistically using two-tailed paired $t$ test and linear regression with the Pearson product-moment correlation coefficient (Altman, 1991). A $p$ value of $<0.05$ was considered significant. All data are reported as the mean \pm standard deviation.

Viubility studies on whole cultures. Matched cultures in $10 \times 35 \mathrm{~mm}$ plates, with the same subculturing history, were exposed to the conditions described for the indicated period of time. For lactate dehydrogenase (LDH) analysis, an aliquot of the culture medium was taken and then the remaining cells were lysed with $0.1 \%$ Triton X-100. After centrifugation, both the initial medium and lysate were assayed for $\mathrm{LDH}$ activity using the LDL-20 kit from Sigma. The amount of LDH released into the medium expressed as a percentage of total activity is reported as percentage cell death.

For direct counting of cell viability, a previously described technique was adapted (Jones and Senft, 1985). Cultures on coverslips were in- cubated with fluorescein diacetate $(20 \mu \mathrm{M})$ and propidium iodide $(5 \mu \mathrm{M})$ for $10 \mathrm{~min}$ at the end of the exposure, and then dried for counting by rapid aspiration of the fluid over the coverslip. Fluorescence microscopy using $360 \mathrm{~nm}$ cxcitation, $395 \mathrm{~nm}$ dichroic, and $457 \mathrm{~nm}$ long-pass filter distinguished clearly between live (green) and dead (red-yellow) cells. Alternatively, cells could be loaded with fura-2 as described above, and then stained with propidium iodide $(5 \mu \mathrm{M})$ and processed similarly, making live cells blue and dead cells red. The numbers of live and dead cells were counted in several contiguous fields at $400 \times$ magnification to yield a total count of $>100$ cells. Other sections of the coverslip were then counted in a similar fashion. More than 800 cells were counted on two coverslips each for each experimental condition ( \pm added external $\mathrm{Ca}^{2+)}$. Percentage cell death for each count was calculated and used to determine the standard deviation reported, which is a measure of variability in counting and scoring as well as experimental outcome. The percentage death reported was determined by summing all the counts for each condition ( \pm added external $\mathrm{Ca}^{2+}$ ). This percentage death, an ovcrall cell death for the entire experiment, differed from the average cell death of the individual field counts by $<0.8 \%$ in all cases. Statistical significance was determined for each experiment by $\chi^{2}$ analysis, with Yates' correction (Altman, 1991), of the $2 \times 2$ frequency table constructed with added external $\mathrm{Ca}^{2}+$ and cell viability as the two dichotomous variables.

Oxidative stress with hydrogen peroxide. Exposure to $\mathrm{H}_{2} \mathrm{O}_{2}$ was made under the same conditions as metabolic inhibition, except that sodium cyanide and 2-deoxyglucose were replaced with $1.0 \mathrm{mM} \mathrm{H}_{2} \mathrm{O}_{2}$, and $\mathrm{KRH}$ buffer contained $5.0 \mathrm{~mm}$ glucose.

\section{Results}

Fura-2 as an indicator of cytoplasmic free calcium. Cells loaded with fura-2 under the conditions described lost $>98 \%$ of their fluorescence upon exposure to $20 \mu \mathrm{M}$ digitonin, which does not lyse endoplasmic reticulum or mitochondria at this concentration, indicating that fura- 2 was localized in the cytoplasm (Lemasters et al., 1990). Cells loaded with fura-2 respondcd to depolarization by $70 \mathrm{~mm}\left[\mathrm{~K}^{+}\right]$buffer with an increase in $\mathrm{Ca}^{2+}$ to more than twice the initial level, while exposure to the calcium ionophore 4-bromo-A23187 (5 $\mu \mathrm{M})$ increased $\mathrm{Ca}^{2+}{ }_{i}>10$-fold. These positive controls demonstrate the predicted responsiveness of completely hydrolyzed fura- 2 in SK-N-SH cells.

Absence of glutamate receptors in $S K-N-S H$. Previous screenings of neuroblastoma lines have uniformly shown the absence of glutamate receptors (Younkin et al., 1993). The RPMI medium used to culture SK-N-SH contains $0.15 \mathrm{~mm}$ L-aspartate and $0.14 \mathrm{~mm}$ L-glutamate, which would usually preclude the successful culture of cells expressing functional glutamate receptors (Banker and Goslin, 1991b). To confirm the absence of glutamate receptors, we tested the $\mathrm{Ca}^{2+}{ }_{i}$ response of SK-N-SH to $1 \mathrm{mM} \mathrm{L-glutamate}$ (sodium salt, $\mathrm{pH} 7.4$ ) in regular $\mathrm{KRH}$ buffer ( $n=8$ cells), as well as in KRH with magnesium omitted, and $10 \mu \mathrm{M}$ glycine and $5 \mathrm{~mm}$ glucose added ( $n-20$ cells). In no case was there any increase in $\mathrm{Ca}^{2+}{ }_{i}$. Cultures incubated with $1 \mathrm{mM}$ L-glutamate and $10 \mu \mathrm{M}$ glycine added to their regular culture medium showed no increased LDH release after $24 \mathrm{hr}$ compared to controls without glutamate and glycine (14.6 \pm $12.4 \%$ cell death vs $11.2 \pm 14.5 \%$ cell death, respectively; $n=$ 4 cultures each, $P>0.5$ ). The NMDA receptor antagonist 2-anninu-phosphonovaleric acid (APV, $50 \mu \mathrm{M}$ ) had no effect on cell death during metabolic inhibition for $210 \mathrm{~min}$, measured by $\mathrm{LDH}$ release $(75.5 \pm 3.6 \%-\mathrm{APV}$ vs $71.8 \pm 3.6 \%+\mathrm{APV}$; $n=5$ cultures each; $P>0.1)$.

Effect of control exposure without metabolic inhibition. The cytoplasmic concentration of fura-2 (proportional to fluorescence at $360 \mathrm{~nm}$ excitation) was stable after a small initial decline in cells incubated in KRH buffer alone, without metabolic inhibition (Fig. 1), indicating that cells remained viable during 


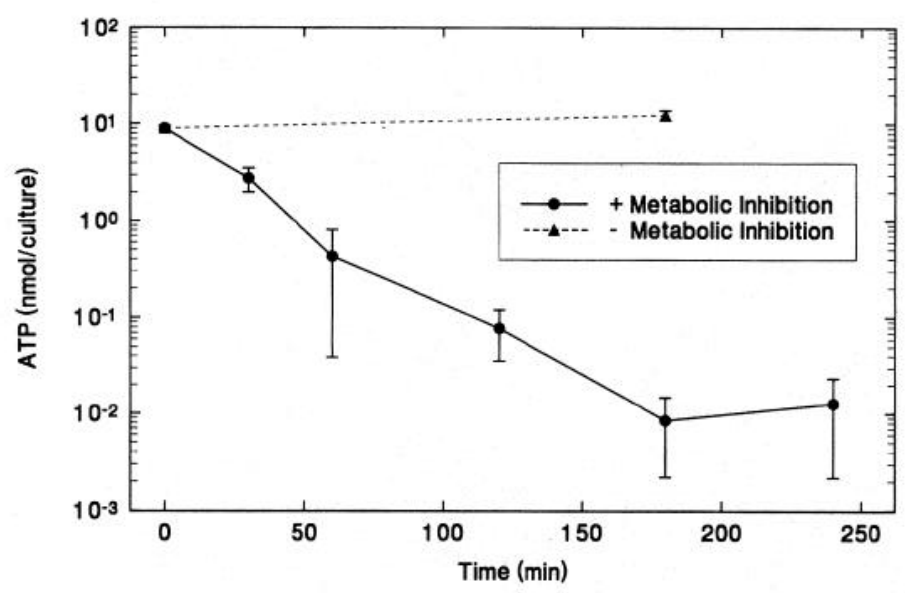

Figure 2. ATP depletion during metabolic inhibition of SK-N-SH cells. Each point is the average of four separate cultures. Error bars are SDs.

the experimental period and did not suffer from phototoxicity or other injury related to fluorescence monitoring. If $20 \mu \mathrm{M}$ digitonin was added after $300 \mathrm{~min}$ (arrow, Fig. 1) to lyse selectively the cytoplasmic membrane and leave endoplasmic reticulum and mitochondria intact (Lemasters et al., 1990), all fura-2 fluorescence disappeared, indicating that fura-2 did not become sequestered in organelles during the experiment. Cells displayed only a small, linear increase in $\mathrm{Ca}^{2+}{ }_{i}$ prior to digitonin treatment during the $300 \mathrm{~min}$ control incubation (Fig. 1). Linear regression analysis gave a statistically significant increase in $\mathrm{Ca}^{2+}{ }_{i}$ with time $(p<0.001)$ that was quantitatively unimpressive: $6.1 \pm$ $2.0 \mathrm{nM} \mathrm{Ca}^{2+}{ }_{i}$ increase per $30 \mathrm{~min}$. Hence, although control cells probably suffered some depletion of energy stores by prolonged incubation without glucose, there was no effect on cell viability within $300 \mathrm{~min}$, and much less effect on $\mathrm{Ca}^{2+}{ }_{i}$ than was seen with metabolic inhibition (below).

Cell injury during metabolic inhibition. Cells subjected to metabolic inhibition with cyanide ( $2.5 \mathrm{~mm})$ and 2-deoxyglucose (10 mм) displayed the biochemical characteristics of hypoxic cells. As illustrated in Figure 2, cellular ATP declined steadily during metabolic inhibition, from $31 \%$ of its initial value at $30 \mathrm{~min}$, to $0.1 \%$ at $180 \mathrm{~min}$. The approximation to a straight line of the logarithmic plot suggests a continuing first-order destruction of ATP throughout at least the first $180 \mathrm{~min}$ of metabolic inhibition. Data beyond that time are severely limited by the accuracy of the analytical technique with such low levels of ATP.

Hypoxia, metabolic inhibition, and other toxins have been reported to cause formation of blebs, rounded protrusions of the plasma membrane (Lemasters et al., 1987; Nieminen et al., 1988; Lemasters et al., 1990; Geeraerts et al., 1991). SK-N-SH cells examined by phase microscopy during metabolic inhibition showed obvious early bleb formation (Fig. 3), documenting the occurrence of injury from metabolic inhibition well before cell death.

Cell death from metabolic inhibition. Cell death during metabolic inhibition was visually apparent by the loss of fura-2 (Fig. 4), corresponding to the abrupt loss of plasma membrane permeability at the time of cell death, and analogous to the release of lactate dehydrogenase, ${ }^{51} \mathrm{Cr}$-labeled proteins, and other intracellular components as assays of cell death. The time of cell death was quantitatively determined by the sudden decrease in fluorescence intensity and image area in the $360 \mathrm{~nm}$ image, since
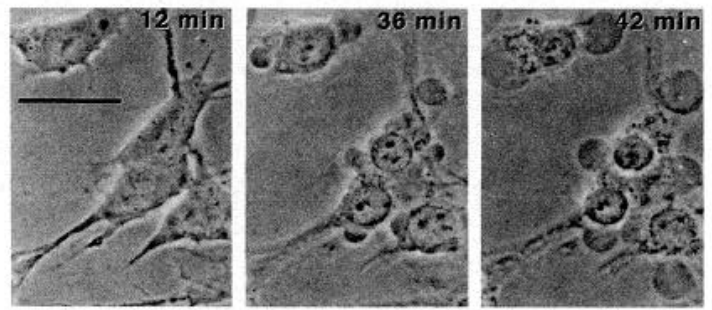

Figure 3. Blebbing of the plasma membrane in SK-N-SH cells during metabolic inhibition. All cells shown were viable at all the time points indicated, as determined by exclusion of propidium iodide. Scale bar, $10 \mu \mathrm{m}$.

$360 \mathrm{~nm}$ is near the isosbestic point of fura-2 with respect to $\mathrm{Ca}^{2+}$, (Fig. 5). Fluorescence $360 \mathrm{~nm}$ decreased to $<5 \%$ of its initial value after cell death (at further time points than shown in Fig. 5; see also Figs. 7, 10, 11), indicating that metabolic inhibition did not cause fura- 2 to become sequestered in organelles that remain intact after cell death. The loss of fura-2 fluorescence at $360 \mathrm{~nm}$ has been shown to correlate temporally with the onset of propidium iodide staining, another widely accepted assay for cell death (Lemasters et al., 1987; Geeraerts et al., 1991). We validated this correlation for the SK-N-SH cell line during metabolic inhibition. As shown in Figure 6, the fura-2 image at $360 \mathrm{~nm}$ excitation diminished and then disappeared at the same time that the propidium iodide image at $490 \mathrm{~nm}$ excitation appeared and then increased. This is quantitated in Figure 7, showing that the time of the abrupt, sustained decrease in fura-2 $360 \mathrm{~nm}$ fluorescence is similar to the time of the abrupt, sustained increase in propidium iodide $490 \mathrm{~nm}$ fluorescence. The small delay in propidium iodide fluorescence probably reflects the need for this dye to diffuse from outside the cell, through the cytoplasm and the nuclear membrane, and bind to nuclear DNA before a change in fluorescence is seen, while the loss of cytoplasmic fura- 2 adjacent to the ruptured plasma membrane is immediately evident. In any event, Figure 7 establishes that an abrupt, sustained decrease in fura- 2 fluorescence $360 \mathrm{~nm}$ is a reasonable measure of cell death in SK$\mathrm{N}-\mathrm{SH}$ during metabolic inhibition.

Neither sodium cyanide $(2.5 \mathrm{~mm})$ nor 2-deoxyglucose (10 mM) alone caused cell death within the observation period of 300 min, while all cells treated with the combination of cyanide and 2-deoxyglucose (metabolic inhibition) died within $300 \mathrm{~min}$. As shown in Figure 8, the median time to cell death during metabolic inhibition was $90 \mathrm{~min}(n=51$ cells from seven separate cultures).

Free cytoplasmic calcium during metabolic inhibition. Typical changes in $\mathrm{Ca}^{2+}{ }_{i}$ in a single SK-N-SH cell are shown in pseudocolor cell images in Figure 4, and quantified in Figure 5. Although there was usually a small increase in $\mathrm{Ca}^{2+}$, shortly after the onset of metabolic inhibition, the majority of the apparent increase in $\mathrm{Ca}^{2+}{ }_{i}$ occurred at the time of cell death, when plasma membrane integrity was lost and there was no longer an effective barrier to the influx of $\mathrm{Ca}^{2+}$ along its large concentration gradient. It is probable that the concentration of $\mathrm{Ca}^{2+}$ inside the volume bounded by the cell membrane increased far beyond the 700 nм seen in Figure 5, since it was equilibrating with buffer containing $2 \mathrm{~mm} \mathrm{Ca}^{2+}$. However, outward diffusion of fura- 2 from the dead cell caused the fluorescent image to shrink and then disappear, and limited the determination of $\mathrm{Ca}^{2+}$ to a short period of time immediately after cell death. 


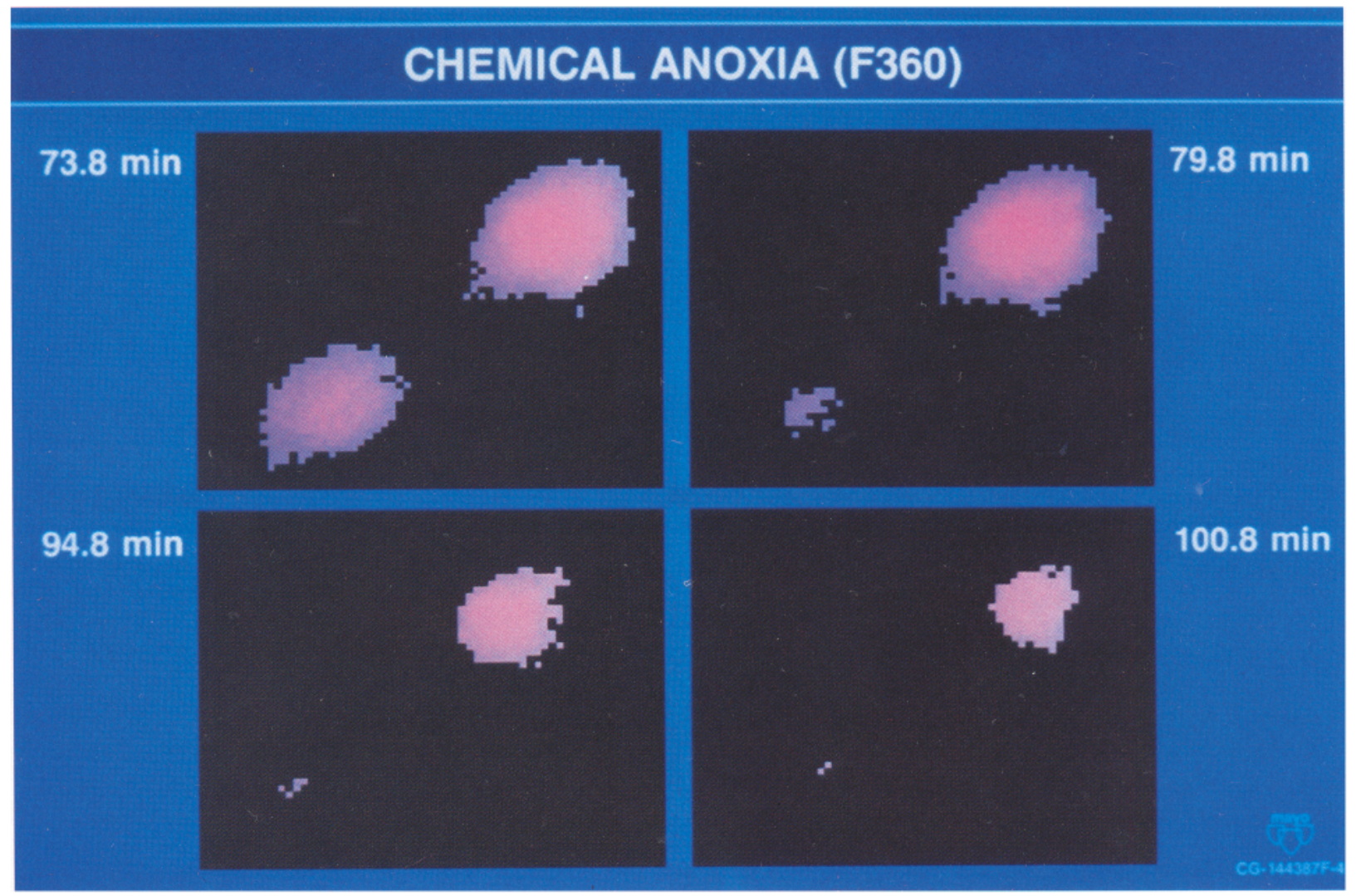

\section{CHEMICAL ANOXIA (F340/F360)}

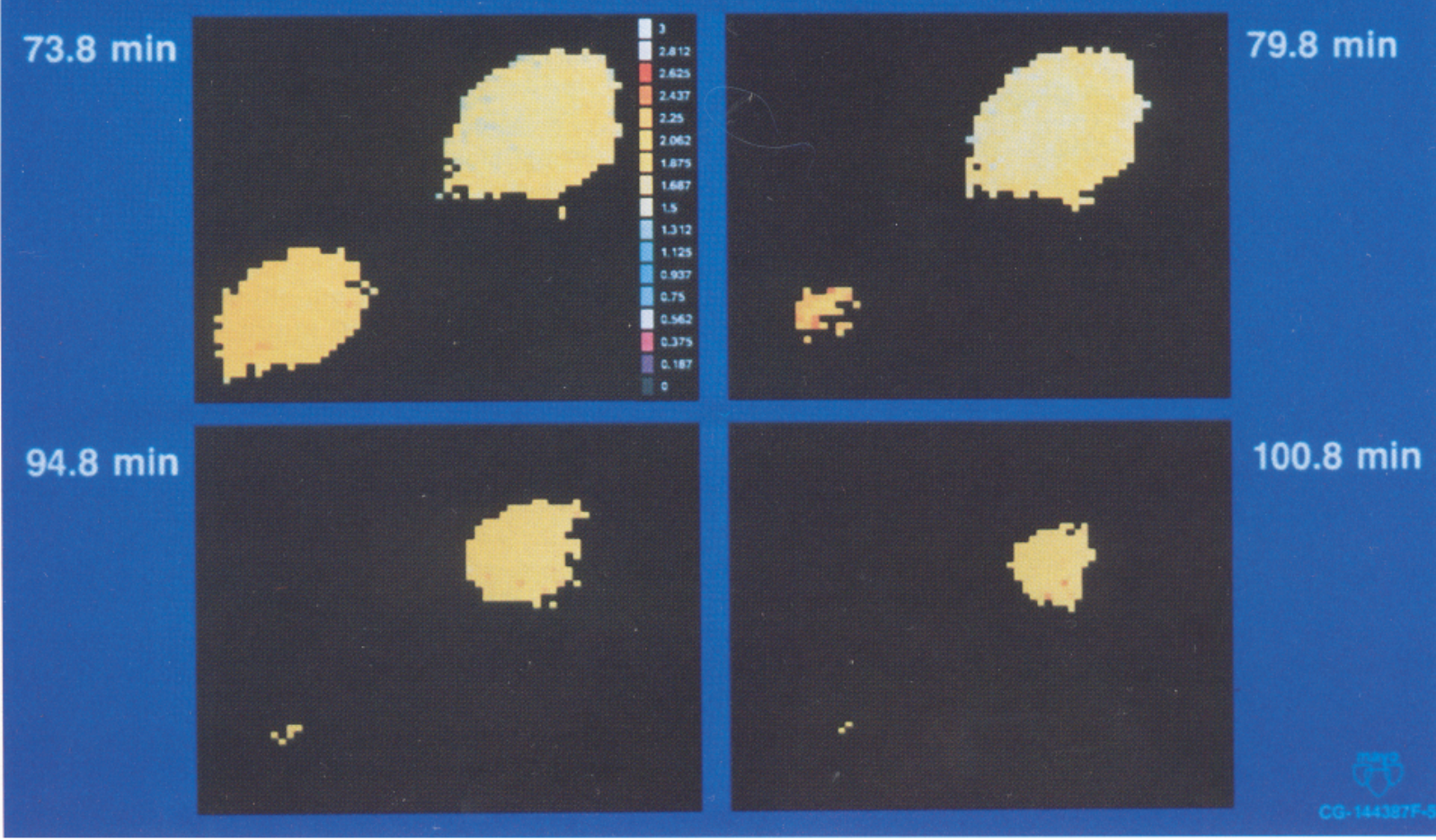


The increase in $\mathrm{Ca}^{2+}$, observed while the SK-N-SH cells were alive occurred within 5-10 min after the initiation of metabolic inhibition, and quickly reached a plateau value. The plateau value remained fairly constant until cell death occurred, as shown in Figure 5. The plateau value was always achieved well before half of the time to cell death. Therefore, to analyze the change in $\mathrm{Ca}^{2+}$, due to metabolic inhibition, we compared the $\mathrm{Ca}^{2+}$ halfway to cell death, $\mathrm{Ca}^{2+}\left(t_{1 / 2}\right)$, with the initial $\mathrm{Ca}^{2+}{ }_{i}, \mathrm{Ca}^{2+}\left(t_{0}\right)$. $\mathrm{Ca}^{2+}{ }_{i}\left(t_{0}\right)$ was $121 \pm 67 \mathrm{nM}$, while $\mathrm{Ca}^{2+}{ }_{j}\left(t_{1 / 2}\right)$ was $171 \pm 116 \mathrm{nM}$. The difference was significant by paired $t$ test $(p<0.0001)$.

Effect of free cytoplasmic calcium on susceptibility to metabolic inhibition. Observing a moderate increase in $\mathrm{Ca}^{2+}{ }_{i}$ during metabolic inhibition is necessary but not sufficient to establish that $\mathrm{Ca}^{2+}$, plays a mechanistically significant role during neuronal death from metabolic inhibition. One prediction that can be made and examined using single-cell experiments is that if elevated $\mathrm{Ca}^{2+}$, causes cell death, the time to cell death should be inversely related to some measure of the change in $\mathrm{Ca}^{2+}{ }_{i}$ during metabolic inhibition. We therefore examined the correlation between $\mathrm{Ca}^{2+}{ }_{i}$ and time to cell death by simple linear regression.

Linear regression analysis showed no significant relationship between time to cell death and either $\mathrm{Ca}^{2+}{ }_{i}\left(t_{0}\right), \mathrm{Ca}^{2+}{ }_{i}\left(t_{1 / 2}\right)$, or the difference between $\mathrm{Ca}^{2+}{ }_{i}\left(t_{1 / 2}\right)$ and $\mathrm{Ca}^{2+}{ }_{i}\left(t_{0}\right), \Delta \mathrm{Ca}^{2+}{ }_{i}\left(t_{1 / 2}-t_{0}\right)$. However, measurement of $\mathrm{Ca}^{\prime+}$, by fura- 2 is more reliable as an indicator of change in $\mathrm{Ca}^{2+}$, than as an indicator of accurate, absolute $\mathrm{Ca}^{2+}$ concentrations (Roe et al., 1990). Therefore, we also analyzed the percentage change in $\mathrm{Ca}^{2+}{ }_{i}$ as a dimensionless parameter reporting relative change rather than absolute values. As shown in Figure 9, when the time to cell death was plotted against percentage change in $\mathrm{Ca}^{2+}{ }_{i}$, the coefficient of determination $\left(r^{2}\right)$ was 0.13 , with $p$ (slope) of 0.009 ; that is, only $13 \%$ of the variation in time to cell death could be attributed to changes in $\% \Delta \mathrm{Ca}^{2+}\left(t_{1 / 2}-t_{0}\right)$, although the quantitatively small correlation that did occur is unlikely to have occurred by chance. Examination of Figure 9 also reveals that there were eight cells ( $16 \%$ of the total) with $<20 \% \Delta \mathrm{Ca}^{2+}{ }_{i}\left(t_{1 / 2}-t_{0}\right)$ that nevertheless died before the median time to death $(90 \mathrm{~min})$.

The effect of $\mathrm{Ca}^{2+}{ }_{i}$ on survival during metabolic inhibition was also examined by using buffer that omitted added $\mathrm{Ca}^{2+}$. As shown in Figure 10, such treatment moderately reduced resting $\mathrm{Ca}^{2+}{ }_{i}$ levels, and almost completely prevented the rise in $\mathrm{Ca}^{2+}$, seen during metabolic inhibition in buffer with $\mathrm{Ca}^{2+}$ added. Nevertheless, preventing the increase in $\mathrm{Ca}^{2+}$, did not prevent cell death (shown in Fig. 10 by the sharp decrease in fluorescence $360 \mathrm{~nm}$ ), and in the small number of cells analyzed did not prevent blebbing and did not markedly prolong cell survival during metabolic inhibition. To determine if preventing an increase in $\mathrm{Ca}^{2+}$, might delay cell death, matched cultures with and without added $\mathrm{Ca}^{2+}$ were subjected to metabolic inhibition and their viability determined at a given time point, as presented in Table 1 . In three different experiments, each using a different assay of cell viability, more cells died in the absence of added $\mathrm{Ca}^{2+}$ than in its presence.

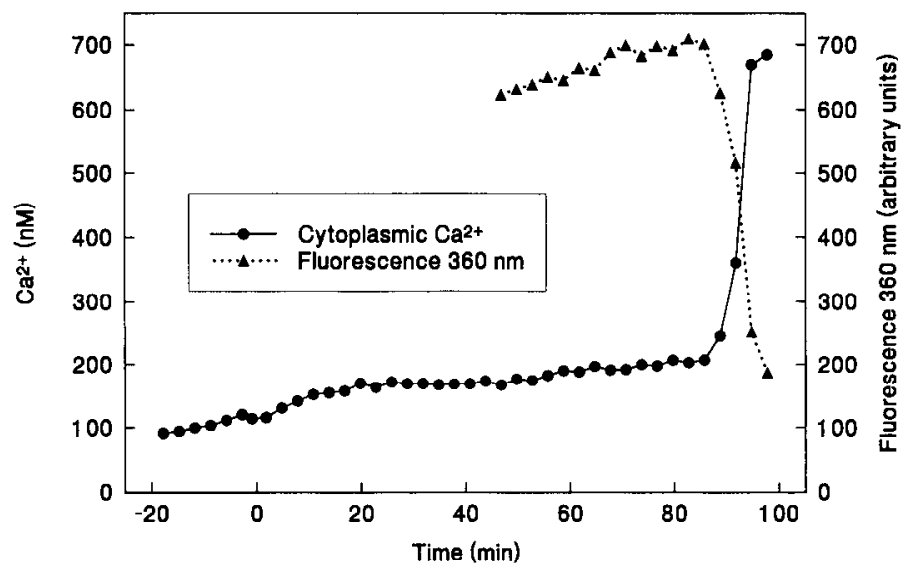

Figure 5. Effect of metabolic inhibition on $\mathrm{Ca}^{2+}{ }_{i}$ and cell membrane integrity (fluorescence $360 \mathrm{~nm}$ ) for a single SK-N-SH ccll, loaded with fura-2. Data are for the upper right cell in Figure 4. The time of cell death is indicated by the sharp decline in fluorescence $360 \mathrm{~nm}$. Fluorescence $360 \mathrm{~nm}$ was multiplied by a constant to put it in the same range as $\mathrm{Ca}^{2+}{ }_{i}$, since it is the change rather than the absolute value of fluorescence $360 \mathrm{~nm}$ that is important in determining cell death. Note the expanded $\mathrm{x}$-axis compared to the control exposure in Figure 1.

Free cytoplasmic calcium during oxidative stress. Hydrogen peroxide toxicity has been shown in other cell types to involve large elevations in $\mathrm{Ca}^{2+}$ ithat are required for toxicity (Ody and Junod, 1985; Hyslop et al., 1986; Geeraerts et al., 1991). We therefore tested it as a positive control to ensure that our system would in fact have detected larger, more toxic elevations in $\mathrm{Ca}^{2+}{ }_{i}$ had they occurred during metabolic inhibition. Figure 11 illustrates the changes in $\mathrm{Ca}^{2+}$, and cell viability during exposure of an $\mathrm{SK}-\mathrm{N}-\mathrm{SH}$ cell to $1 \mathrm{mM} \mathrm{H}_{2} \mathrm{O}_{2}$, showing a fivefold increase in $\mathrm{Ca}^{2+}{ }_{i}\left(t_{1 / 2}\right)$ compared to $\mathrm{Ca}^{2+}{ }_{i}\left(t_{0}\right)$, from 80 to $400 \mathrm{~nm}$. The initial increase in $\mathrm{Ca}^{2+}$, was more delayed than during metabolic inhibition, possibly related to the presence of glucose in the experimental buffer with $\mathrm{H}_{2} \mathrm{O}_{2}$. Glucose was added to better mimic the in vivo conditions that accompany oxidative stress during reperfusion. Figure 12 demonstrates that membrane blebbing also occurred early during oxidative injury, in a time course similar to the increase in $\mathrm{Ca}^{2+}{ }_{i}$. These experiments were not amenable to the same type of analysis as the metabolic inhibition experiments. The rise in $\mathrm{Ca}^{2+}$, was more delayed and more sustained, so that $\mathrm{Ca}^{2+}{ }_{i}$ at half the time to cell death continued to increase meaningfully. Nevertheless, the demonstration of large increases in $\mathrm{Ca}^{2+}$ i during $\mathrm{H}_{2} \mathrm{O}_{2}$ cytotoxicity is a positive control and serves to strengthen our observation of minimal changes in $\mathrm{Ca}^{2+}$, during metabolic inhibition.

\section{Discussion}

Our model was specifically designed to create a lethal metabolic insult similar to the ATP depletion of ischemia in a cell line of neuronal origin, while excluding excitotoxicity, the effects of

Figure 4. Effect of metabolic inhibition on fura-2 images of single SK-N-SH cells near the time of cell death. Images are pseudocolor representations of cells at the indicated times after metabolic inhibition ( $2.5 \mathrm{~mm} \mathrm{NaCN}, 10 \mathrm{~mm}$ 2-deoxyglucose; added at 0 min) was begun. The upper image represents fluorescence with excitation at $360 \mathrm{~nm}(F 360)$, which is isosbestic with respect to $\mathrm{Ca}^{2+}{ }_{\text {, }}$ and therefore a measure of cell membrane integrity. The $F 360$ image begins to contract and diminish at the time of cell death as fura-2 diffuses from the cytoplasm. The lower image represents the pixel-by-pixel ratio of fluorescence at $340 \mathrm{~nm}$ to that at $360 \mathrm{~nm}$ for the same cells, with pseudocolor ratio scale as shown; an increasing ratio (more red pixels) implies increasing $\mathrm{Ca}^{2+}{ }_{i}$ (seen primarily after cell death). 
Figure 6. Concurrent imaging of fura-2 and propidium iodide fluorescence in SK-N-SH cells during metabolic inhibition. Images are gray scale representations of cells at the indicated times after metabolic inhibition $(2.5 \mathrm{~mm}$ $\mathrm{NaCN}, 10 \mathrm{~mm}$ 2-deoxyglucose; added at $0 \mathrm{~min}$ ) was begun. The lower images represent fluorescence with excitation at $360 \mathrm{~nm}$ as a measure of cytoplasmic fura- 2 concentration. The upper images represent fluorescence with excitation at $490 \mathrm{~nm}$ as a measure of intracellular propidium iodide. When cell membrane integrity is lost at the time of cell death, the fura- 2 image begins to contract and diminish as fura-2 diffuses from the cytoplasm, while the propidium iodide image appears and enlarges as propidium iodide diffuses from outside the cell into the nucleus and binds to DNA, with a marked increase in fluorescence yield.
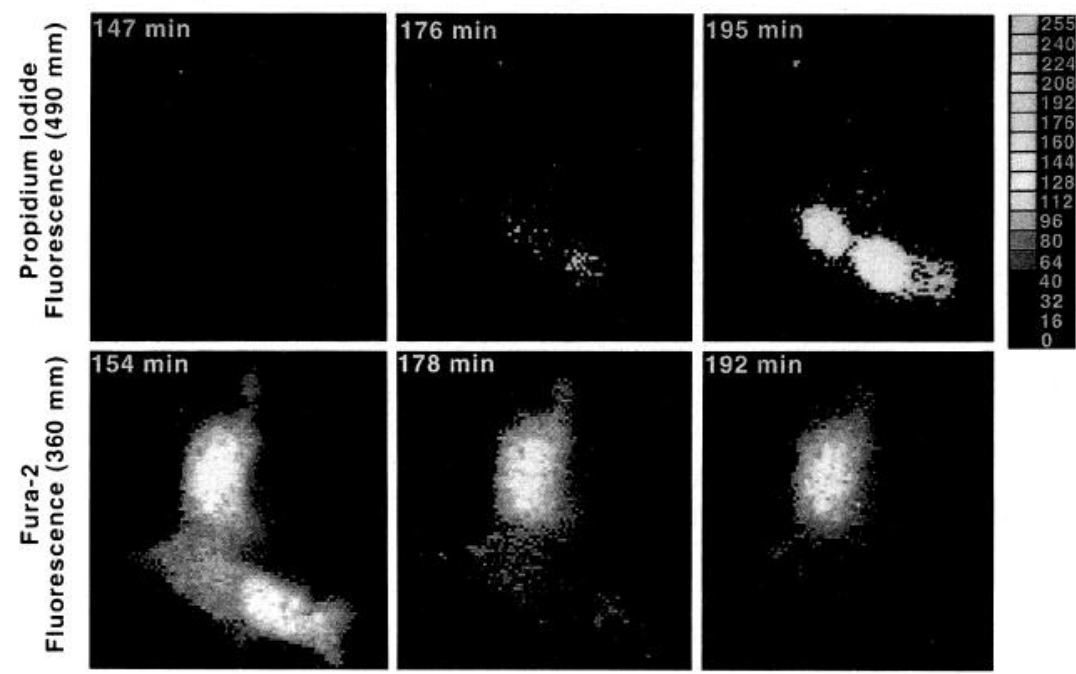

non-neuronal cells, the averaging of dead with viable cells, and the use of cells that were irreversibly injured prior to metabolic inhibition. Hence, our results provide new information about the basic neuronal $\mathrm{Ca}^{2+}{ }_{i}$ response to hypoxia, upon which other influences such as excitotoxicity must act. This is the first such report using single cells examined continuously until the time of cell death, with individual changes in $\mathrm{Ca}^{2+}$, correlated with individual times of cell death.

Although we observed a statistically significant increase in $\mathrm{Ca}^{2+}$, during metabolic inhibition in the absence of glutamate release and receptors, the increase is unlikely to have much physiological significance; (1) quantitatively, the $50 \mathrm{~nm}$ increase in $\mathrm{Ca}^{2+}$, we observed is moderate and well within the range of $\mathrm{Ca}^{2+}{ }_{i}$ changes seen during normal neural function; (2) some SK$\mathrm{N}$-SH cells died in less than the median time to cell death, with no or $<20 \%$ increase in $\% \Delta \mathrm{Ca}^{2+}{ }_{i}\left(t_{1 / 2}-t_{0}\right)$; (3) the correlation between time to cell death and increase in $\mathrm{Ca}^{2+}{ }_{i}$, while present, was extremely weak; and (4) preventing the increase in $\mathrm{Ca}^{2+}$, by

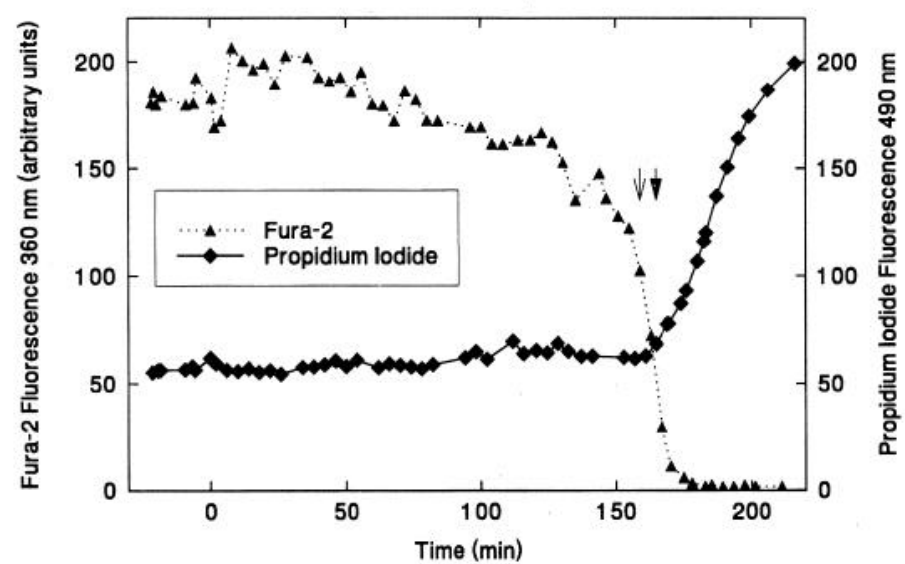

Figure 7. Quantitative comparison of fura-2 and propidium iodide fluorescence as indicators of time of cell death in SK-N-SH. The graph is for the cell on the lower right of Figure 6. The open arrow indicates the time at which an abrupt, sustained decrease in fura-2 fluorescence $(360 \mathrm{~nm})$, beyond the gradual decrease seen previously, begins. The solid arrow indicates the time at which an abrupt, sustained increase in propidium iodide fluorescence $(490 \mathrm{~nm})$, beyond the stable background level seen previously, begins. omitting $\mathrm{Ca}^{2+}$ from the buffer did not prevent cell death from metabolic inhibition. Although the increase in cytoplasmic volume accompanying bleb formation might have acted to dilute and minimize the $\mathrm{Ca}^{2+}$, increase during metabolic inhibition, it cannot account solely for the lack of a large $\mathrm{Ca}^{2+}{ }_{i}$ increase, since a large $\mathrm{Ca}^{2+}$, increase was seen during oxidative stress despite blebbing. Our results confirm the importance of studying glutamate receptor activation as a source of potentially toxic $\mathrm{Ca}^{2+}$, elevation during hypoxia (Goldberg and Choi, 1990), since the underlying cellular response alone is unlikely to cause $\mathrm{Ca}^{2+}{ }_{i}$ mediated neuronal death.

Our results complement those of Friedman and Haddad (1993), who monitored $\mathrm{Ca}^{2+}$, with fluo-3 in acutely dissociated hippocampal neurons, during anoxia produced with the $\mathrm{O}_{2} \mathrm{scav}$ enger dithionite. They tested the effects of $\mathrm{Ca}^{2+}$ and $\mathrm{Na}^{+}$modulation by buffer changes and channel blockers during anoxia, and found that preventing an increase in $\mathrm{Ca}^{2+}{ }_{i}$ did not prevent cell death during anoxia. Other studies in single neurons (Duchen et al., 1990; Dubinsky and Rothman, 1991) have reported the effect of cyanide alone, in concentrations near those used in our study, on $\mathrm{Ca}^{2+}$. Duchen et al. (1990) found a $79 \mathrm{~nm}$ increase

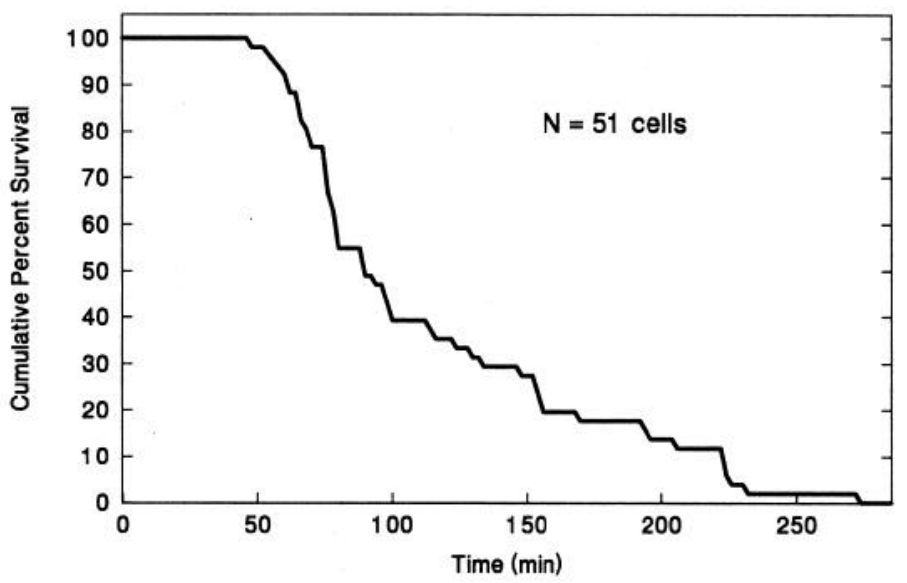

Figure 8. Cumulative survival curve for all individual SK-N-SH cells analyzed during metabolic inhibition $(2.5 \mathrm{~mm} \mathrm{NaCN}, 10 \mathrm{~mm}$ 2-deoxyglucose; added at $0 \mathrm{~min}$ ). The data represent 51 cells from seven separate cultures. 


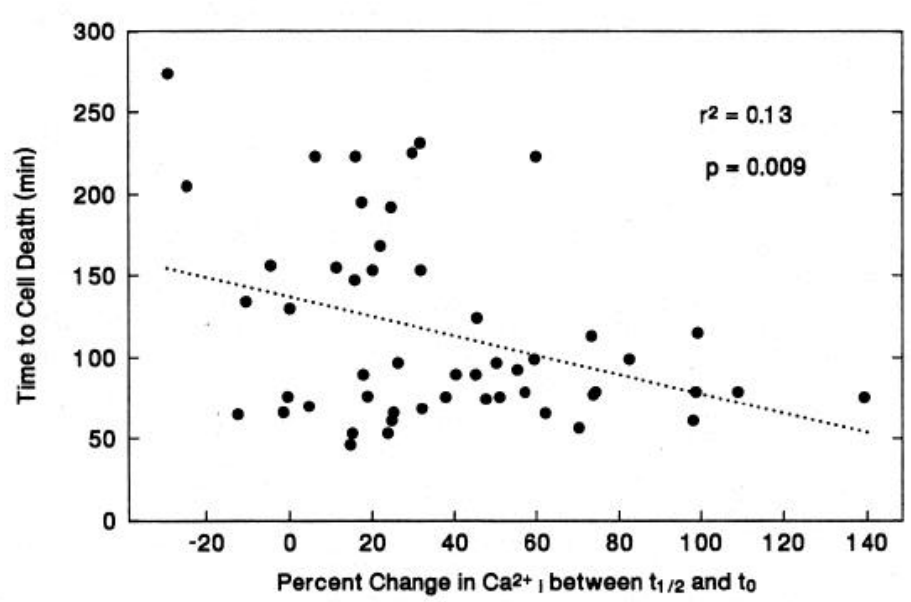

Figure 9. Linear regression analysis of time to cell death versus percentage change in $\mathrm{Ca}^{2+}{ }_{i}$. Each point represents a single cell. The line of best fit is (time to cell death) $=-0.59\left[\% \Delta \mathrm{Ca}^{2+}\left(t_{1 / 2}-t_{0}\right)\right]+137$.

in $\mathrm{Ca}^{2+}$, in acutely dissociated mouse dorsal root ganglion neurons exposed to $2 \mathrm{~mm}$ cyanide, similar to the $50 \mathrm{~nm}$ we observed. Dubinsky and Rothman (1991) found an $800 \mathrm{~nm}$ increase in $\mathrm{Ca}^{2+}$, in cultured rat hippocampal neurons exposed to $3 \mathrm{~mm}$ cyanide, but this probably reflected endogenous glutamate release during cyanide exposure. In neither study was cyanide toxic. Shorter exposure periods than ours were used, more appropriate to the objectives of those studies (10-30 min for hippocampal neurons, 2-10 min for sensory neurons), and no glycolytic inhibitor was added. Although cyanide is an efficient inhibitor of cytochrome oxidase $\left(K_{i} \approx 10^{-7} \mathrm{M}\right)$ (Hewitt and Nicholas, 1963), it must compete with the oxygen also present in these experimental systems. Also significant, for hippocampal cells, is the tendency of embryonic cells to be more resistant to hypoxia than adult cells (Friedman and Haddad, 1993), and for cultured cells, particularly tumor lines, to shift to a more glycolytic metabolism with greater glycogen stores (Penttila and Trump, 1974; Freshney, 1987; Jenkins, 1991). This necessitated the concomitant use of 2-deoxyglucose as a glycolytic inhibitor (Hochster, 1963) in our experiments, in order to achieve an observable rate of cell death.

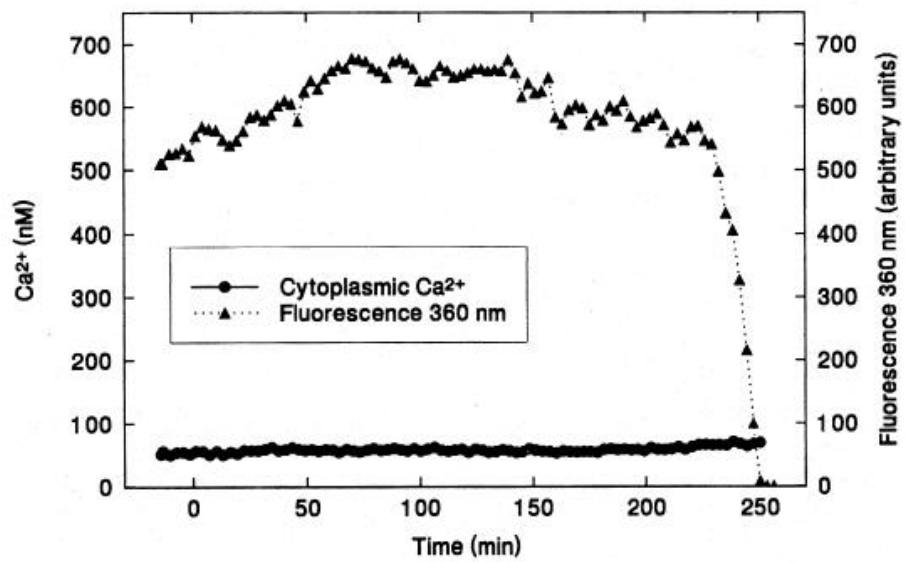

Figure 10. Effect of omitting added external calcium during metabolic inhibition. Metabolic inhibition ( $2.5 \mathrm{~mm} \mathrm{NaCN}, 10 \mathrm{~mm} 2$-deoxyglucose) was begun at $0 \mathrm{~min}$, in $\mathrm{KRH}$ buffer with no calcium added. One cell typical of eight, except that a longer-lived cell was chosen to demonstrate the stability of $\mathrm{Ca}^{2+}{ }_{i}$ even during a prolonged period of metabolic inhibition.

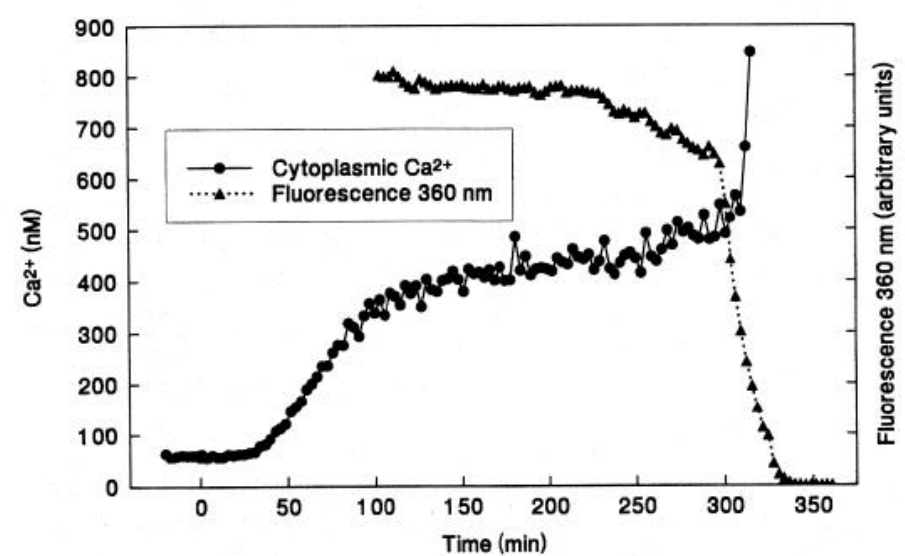

Figure 11. Effect of oxidative stress on $\mathrm{Ca}^{2+}{ }_{i}$ and cell membrane integrity (fluorescence $360 \mathrm{~nm}$ ) for a single SK-N-SH cell, loaded with fura-2. Hydrogen peroxide $(1.0 \mathrm{~mm})$ was added at $0 \mathrm{~min}$. Cell death is indicated by the abrupt decrease in fluorescence $360 \mathrm{~nm}$. Fluorescence $360 \mathrm{~nm}$ was multiplied by a constant to put it in the same range as $\mathrm{Ca}^{2+}{ }_{i}$, since it is the change rather than the absolute value of fluorescence $360 \mathrm{~nm}$ that is important in determining cell death. One cell typical of four.

There are many potential pitfalls in using fura- 2 as a calcium indicator. Our system reported physiologically reasonable initial values for $\mathrm{Ca}^{2+}{ }_{i}$, excluded organellar noncytoplasmic fura-2, and used $360 \mathrm{~nm}$ rather than $380 \mathrm{~nm}$ as a second wavelength to minimize contributions from incompletely hydrolyzed, calcium-insensitive fura-2 AM esters (Roe et al., 1990). Cells observed with our system responded appropriately to agents known to elevate $\mathrm{Ca}^{2+}{ }_{i}$. Our findings confirm the hazard of assaying many cells simultaneously for $\mathrm{Ca}^{2+}$, regardless of the analytic technique, without excluding the effect of dead cells on apparent $\mathrm{Ca}^{2+}{ }_{i}$, for example, in cell suspensions using aequorin luminescence (Snowdowne et al., 1985), and in perfused organs using a calcium-sensitive fluorophore (Uematsu et al., 1988) or a calcium-binding, fluorinated NMR probe (Murphy et al., 1990). The increase in $\mathrm{Ca}^{2+}{ }_{i}$ prior to cell death in our experiments was far less than the massive increase that occurred at the time of cell death. The increase in apparent $\mathrm{Ca}^{2+}$, when plasma membrane integrity is irreversibly lost is an effect, not the cause, of cell death, and bears no relationship to the mechanism of cell death during metabolic inhibition.

In contrast to the effect of metabolic inhibition, hydrogen peroxide at a concentration near that achieved locally during activation of neutrophils (Shayevitz et al., 1991) caused a major rise in $\mathrm{Ca}^{2+}{ }_{i}$ prior to cell death. Hydrogen peroxide is an obligatory breakdown product of the superoxide radical that may be produced during reperfusion, and is more toxic than superoxide
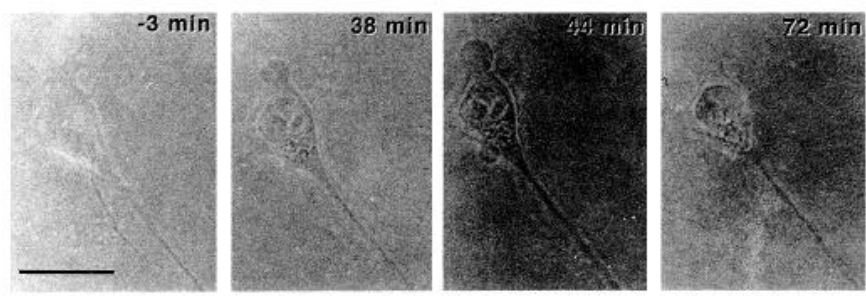

Figure 12. Production of membrane blebbing by oxidative stress. Hydrogen peroxide $(1.0 \mathrm{~mm})$ was added at $0 \mathrm{~min}$. The cell shown was viable at every time point illustrated, as determined by exclusion of propidium iodide. Scale bar, $10 \mu \mathrm{m}$. 
Table 1. Effect of buffer $\mathrm{Ca}^{2+}$ on cell death from metabolic inhibition

\begin{tabular}{llll} 
& & \multicolumn{2}{l}{ Percentage cell death } \\
\cline { 3 - 4 } Time & Method of determining cell death & No added $\mathrm{Ca}^{2+}$ & $+2 \mathrm{mM} \mathrm{Ca}^{2+}$ \\
\hline $140 \mathrm{~min}$ & Propidium iodide/fluorescein diacetate stain & $57.8 \pm 5.6$ & $31.2 \pm 3.7$ \\
$180 \mathrm{~min}$ & Propidium iodide/fura-2 stain & $65.5 \pm 6.7$ & $56.4 \pm 10.2$ \\
$210 \mathrm{~min}$ & Lactate dehydrogenase release & $98.3 \pm 2.4$ & $75.5 \pm 3.6$
\end{tabular}

Each line represents simultaneous exposure to metabolic inhibition ( $2.5 \mathrm{~mm}$ cyanide, $10 \mathrm{~mm}$ 2-deoxyglucose) of matched cultures ( $n=2$ cultures for fluorescent stains, $n=4$ cultures for lactate dehydrogenase, for each condition $\pm \mathrm{Ca}^{2+}$ ). For each experiment, the difference between $\pm \mathrm{Ca}^{2+}$ was statistically significant $(p<0.05)$.

to endothelial cells (Ody and Junod, 1985; Geeraerts et al., 1991). Although fewer experiments with hydrogen peroxide were performed, and the analysis is therefore more limited than that with metabolic inhibition, the results suggest that $\mathrm{Ca}^{2+}$ is more likely to play a major role during oxidative stress (e.g., reperfusion) than during ischemia. This is consistent with those studies reporting beneficial effects of calcium antagonists during in vivo experiments involving both ischemia and reperfusion prior to analysis of outcome (Choi, 1988; Siesjö, 1989; Siesjö and Bengtsson, 1989). The results also illustrate the benefits of being able to analyze single cells under conditions allowing the separation of hypoxia-like conditions from oxidative stress.

This study was designed so that the concentration of $\mathrm{Ca}^{2+}{ }_{i}$ reported was averaged over the entire cytoplasm of the single cell. Occasionally, we would observe localized increases in $\mathrm{Ca}^{2+}{ }_{i}$ just below the plasma membrane, or in bleb-like outpouchings of the plasma membrane. Further experiments with greater spatial resolution will be required to determine how consistent this finding is, and its significance. Intracellular gradients of $\mathrm{Ca}^{2+}$, in neurons have been reported (Connor et al., 1988; Llinas et al., 1992), and our data do not exclude the possibility that localized, subcellular increases in $\mathrm{Ca}^{2+}$, could have an etiologic role in hypoxic neuronal death, although increased $\mathrm{Ca}^{2+}$, in blebs in hepatocytes during hypoxia was not causally associated with cell death (Nieminen et al., 1988).

In conclusion, $\mathrm{Ca}^{2+}$ increases minimally during metabolic inhibition in SK-N-SH cells, and this increase does not appear to contribute to the mechanisms of cell death.

\section{References}

Altman DG (1991) Practical statistics for medical research. New York: Chapman and Hall.

$\mathrm{Au} \mathrm{JL}, \mathrm{Su} \mathrm{MH}$, Wientjes MG (1989) Extraction of intracellular nucleosides and nucleotides with acetonitrile. Clin Chem 35:48-51.

Banker G, Goslin K' (1991a) Types of nerve cell cultures, their advantages and limitations. In: Culturing nerve cells (Banker G, Goslin K eds), pp 11-39. Cambridge, MA: MIT Press.

Banker G, Goslin K (1991b) Primary dissociated cell cultures of neural tissue. In: Culturing nerve cells (Banker $\mathrm{G}$, Goslin K eds), pp 41-74. Cambridge, MA: MIT Press.

Barnes EN, Biedler JL, Spengler BA, Lyser KM (1981) The fine structure of continuous human neuroblastoma lines SK-N-SH, SK-N-BE(2), and SK-N-MC. In Vitro 17:619-631.

Bronk SF, Gores GJ (1991) Acidosis protects against lethal oxidative injury of liver sinusoidal endothelial cells. Hepatology 14:150-157.

Cheung JY, Bonventre JV, Malis CD, Leaf A (1986) Calcium and ischemic injury. N Engl J Med 314:1670-1676.

Choi DW (1988) Calcium-mediated neurotoxicity: relationship to specific channel types and role in ischemic damage. Trends Neurosci 11: $465-469$.

Collins F, Schmidt MF, Guthrie PB, Kater SB (1991) Sustained increase in intracellular calcium promotes neuronal survival. J Neurosci $11: 2582-2587$.

Connor JA, Wadman WJ, Hockberger PE, Wong RK (1988) Sustained dendritic gradients of $\mathrm{Ca}^{2+}$ induced by excitatory amino acids in CA 1 hippocampal neurons. Science 240:649-653.

Dubinsky JM (1993) Intracellular calcium levels during the period of delayed excitotoxicity. J Neurosci 13:623-631.

Dubinsky JM, Rothman SM (1991) Intracellular calcium concentrations during "chemical hypoxia" and excitotoxic neuronal injury. J Neurosci 11:2545-2551.

Duchen MR, Valdeolmillos M, O'Neill SC, Eisner DA (1990) Effects of metabolic blockade on the regulation of intracellular calcium in dissociated mouse sensory neurones. J Physiol (Lond) 424:411-426.

Farber JL (1990) The role of calcium in lethal cell injury. Chem Res Toxicol 3:503-508.

Fisher SK, Domask LM, Roland RM (1989) Muscarinic receptor regulation of cytoplasmic $\mathrm{Ca}^{2+}$ concentrations in human SK-N-SH neuroblastoma cells: $\mathrm{Ca}^{2+}$ requirements for phospholipase $\mathrm{C}$ activation. Mol Pharmacol 35:195-204.

Freshney RI (1987) Culture of animal cells. New York: Liss.

Friedman JE, Haddad GG (1993) Major differences in $\mathrm{Ca}^{2+}$, response to anoxia between neonatal and adult rat $\mathrm{CA} 1$ neurons: role of $\mathrm{Ca}^{2+}$ 。 and $\mathrm{Na}^{+}{ }_{0} . \mathrm{J}$ Neurosci 13:63-72.

Gasbarrini A, Borle AB, Farghali H, Bender C, Francavilla A, Van Thiel D (1992) Effect of anoxia on intracellular ATP, $\mathrm{Na}^{+}{ }_{i}, \mathrm{Ca}^{2+}, \mathrm{Mg}^{2+}{ }_{i}$, and cytotoxicity in rat hepatocytes. J Biol Chem 267:6654-6663.

Geeraerts MD, Ronveaux Dupal MF, Lemasters JJ, Herman B (1991) Cytosolic free $\mathrm{Ca}^{2+}$ and proteolysis in lethal oxidative injury in endothelial cells. Am J Physiol 261:C889-C896.

Goldberg MP, Choi DW (1990) Intracellular free calcium increases in cultured cortical neurons deprived of oxygen and glucose. Stroke 21 [Suppl III]:75-77.

Groskreutz JL, Bronk SF, Gores GJ (1992) Ruthenium red delays the onset of cell death during oxidative stress of rat hepatocytes. Gastroenterology 102:1030-1038.

Grynkiewicz G, Poenie M, Tsien RY (1985) A new generation of $\mathrm{Ca}^{2+}$ indicators with greatly improved fluorescence properties. J Biol Chem 260:3440-3450.

Hartley DM, Kurth MC, Bjerkness L, Weiss JH, Choi DW (1993) Glutamate receptor-induced ${ }^{45} \mathrm{Ca}^{2+}$ accumulation in cortical cell culture correlates with subsequent neuronal degeneration. J Neurosci 13 : 1993-2000.

Hewitt EJ, Nicholas DJD (1963) Cations and anions: inhibitions and interactions in metabolism and in enzyme activity. In: Metabolic inhibitors, Vol 2 (Hochster RM, Quastel JH, eds), pp 311-436. New York: Academic.

Hochster RM (1963) Hexose and pentose analogues. In: Metabolic inhibitors, Vol 1 (Hochster RM, Quastel JH, eds), pp 131-153. New York: Academic.

Hyslop PA, Hinshaw DB, Schraufstatter IU, Sklar LA, Spragg RG, Cochrane CG (1986) Intracellular calcium homeostasis during hydrogen peroxide injury to cultured P388D1 cells. J Cell Physiol 129: $356-366$.

Jenkins N (1991) Growth factors. In: Mammalian cell biotechnology (Butler M, ed), pp 39-56. New York: Oxford UP.

Jones DP (1981) Determination of pyridine dinucleotides in cell extracts by high-performance liquid chromatography. J Chromatogr 225:446-449.

Jones KH, Senft JA (1985) An improved method to determine cell viability by simultaneous staining with fluorescein diacetate-propidium iodide. J Histochem Cytochem 33:77-79.

Kluge H (1991) Calcium and hypoxic/ischemic brain damage-some critical and conceptual remarks. Exp Pathol 42:239-244.

Kostyuk PG (1991) Perfusion of nerve cells and separation of sodium 
and calcium currents. In: Cellular neurobiology: a practical approach (Chad J, Wheal H, eds), pp 121-136. New York: Oxford UP.

Kroll DA, Caplan RA, Posner K, Ward RJ, Cheney FW (1990) Nerve injury associated with anesthesia. Anesthesiology 73:202-207.

Lambert DG, Ghataorre AS, Nahorski SR (1989) Muscarinic receptor binding characteristics of a human neuroblastoma SK-N-SH and its clones SH-SY5Y and SH-EP1. Eur J Pharmacol 165:71-77.

Lemasters JJ, DiGuiseppi J, Nieminen AL, Herman B (1987) Blebbing, free $\mathrm{Ca}^{2+}$ and mitochondrial membrane potential preceding cell death in hepatocytes. Nature 325:78-81.

Lemasters JJ, Gores GJ, Nieminen AL, Dawson TL, Wray BE, Herman B (1990) Multiparameter digitized video microscopy of toxic and hypoxic injury in single cells. Environ Health Perspect 84:83-94.

Llinas R, Sugimori M, Silver RB (1992) Microdomains of high calcium concentration in a presynaptic terminal. Science 256:677-679.

Marsh JD, Smith TS (1991) Calcium overload and ischemic myocardial injury. Circulation 83:709-711.

Meyer FB (1989) Calcium, neuronal hyperexcitability and ischemic injury. Brain Res Brain Res Rev 14:227-243.

Miller RJ (1987) Multiple calcium channels and neuronal function. Science 235:46-52.

Murphy E, Levy L, Raju B, Steenbergen C, Gerig JT, Singh P, London RE (1990) Measurement of cytosolic calcium using 19F NMR. Environ Health Perspect 84:95-98.

Nieminen AL, Gores GJ, Wray BE, Tanaka Y, Herman B, Lemasters JJ (1988) Calcium dependence of bleb formation and cell death in hepatocytes. Cell Calcium 9:237-246.

Ody C, Junod AF (1985) Effect of variable glutathione peroxidase activity on $\mathrm{H}, \mathrm{O}$,-related cytotoxicity in cultured aortic endothclial cells. Proc Soc Exp Biol Med 180:103-111.

Ogura A, Miyamoto M, Kudo Y (1988) Neuronal death in vitro: parallelism between survivability of hippocampal neurones and sustained elevation of cytosolic $\mathrm{Ca}^{2+}$ after exposure to glutamate receptor agonist. Exp Brain Res 73:447-458.

Orrenius S, McConkey DJ, Nicotera P (1991) Role of calcium in toxic and programmed cell death. Adv Exp Med Biol 283:419-425.

Partridge LD, Swandulla D (1988) Calcium-activated non-specific cation channels. Trends Neurosci 11:69-72.

Penttila A, Trump BF (1974) Extracellular acidosis protects Ehrlich ascites tumor cells and rat renal cortex against anoxic injury. Science 185:277-278.
Roe MW, Lemasters JJ, Herman B (1990) Assessment of fura-2 for measurements of cytosolic free calcium. Cell Calcium 11:63-73.

Ross RA, Spengler BA, Biedler JL (1983) Coordinate morphological and biochemical interconversion of human neuroblastoma cells. $J$ Natl Cancer Inst 71:741-747.

Sadée W, Yu VC, Richards ML, Preis PN, Schwab MR, Brodsky FM, Biedler JL (1987) Expression of neurotransmitter receptors and myc protooncogenes in subclones of a human neuroblastoma cell line. Cancer Res 47:5207-5212.

Shayevitz JR, Varani J, Ward PA, Knight PR (1991) Halothane and isoflurane increase pulmonary artery endothelial cell sensitivity to oxidant-mediated injury. Anesthesiology 74:1067-1077.

Siesjö BK (1986) Calcium and ischemic brain damage. Eur Neurol 25[Suppl 1]:45-56.

Siesjö BK (1989) Calcium and cell death. Magnesium 8:223-237.

Siesjö BK, Bengtsson F (1989) Calcium fluxes, calcium antagonists, and calcium-related pathology in brain ischemia, hypoglycemia, and spreading depression: a unifying hypothesis. J Cereb Blood Flow Metab 9:127-140.

Siesjö BK, Memezawa H, Smith ML (1991) Neurocytotoxicity: pharmacological implications. Fundam Clin Pharmacol 5:755-767.

Snowdowne KW, Freudenrich CC, Borle AB (1985) The effects of anoxia on cytosolic free calcium, calcium fluxes, and cellular ATP levels in cultured kidney cells. J Biol Chem 260:11619-11626.

Trump BF, Berezesky IK, Smith MW, Phelps PC, Elliget KA (1989) The relationship between cellular ion deregulation and acute and chronic toxicity. Toxicol Appl Pharmacol 97:6-22.

Uematsu D, Greenberg JH, Reivich M, Karp A (1988) In vivo measurement of cytosolic free calcium during cerebral ischemia and reperfusion. Ann Neurol 24:420-428.

van Zwieten PA (1993) Protective effects of calcium antagonists in different organs and tissues. Am Heart J 125:566-571.

Wetzels JF, Burke TJ, Schrier RW (1992) Calcium channel blockers: protective effects in ischemic acute renal failure. Ren Fail 14:327332.

Younkin DP, Tang C-M, Hardy M, Reddy UR, Shi Q-Y, Pleasure SJ, Lee VM-Y, Pleasure D (1993) Inducible expression of neuronal glutamate receptor channels in the NT2 human cell line. Proc Natl Acad Sci USA 90:2174-2178. 